\title{
Photo Quiz : Dermatomycosis
}

患者 81 歳, 男性. 約 1 カ前より右顔面, 頸部に痒みのある発疹が生じたため受診. 前 立腺癌の治療中である. HCV 抗体陽性. 年余にわたり足爪に混濁があるという. 身体診 察に先立つ医療面接中に, 右耳前から類にかけて境界のやや不明瞭な不整形の紅斑の存在 に気付き，左前額から前頭部にも一部境界不明瞭な落屑斑が認められた（図 1). 右㚘頁, 前頭落屑より KOH 直接鏡検法で糸状菌陽性, 白癬と診断した。

1. 最も可能性の高い原因菌はなにか?

2. 若手医師の指導に際して，この例のポイントはどこにあるか?

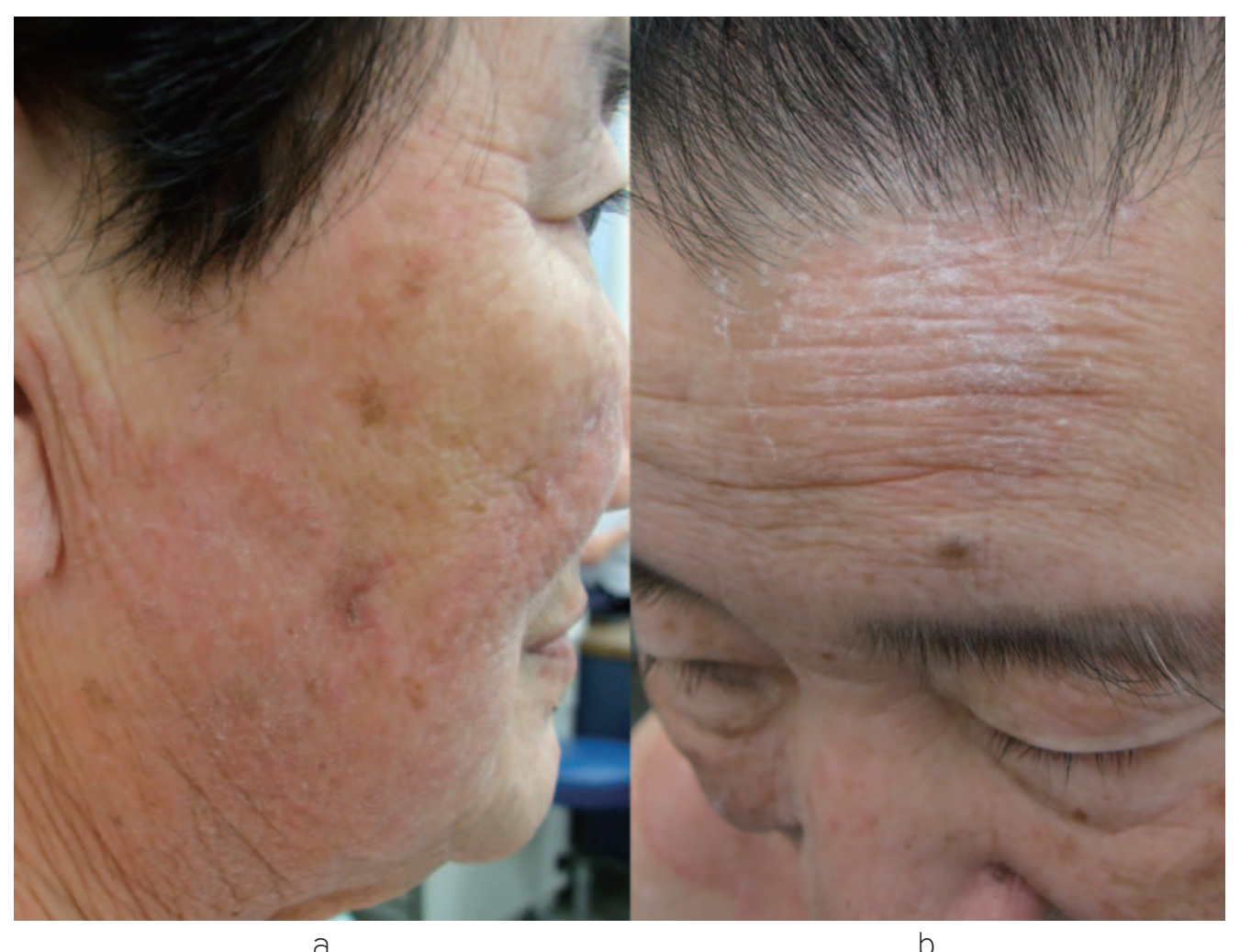

図 1 初診時の皮膚所見. a 顔面. b 額. ともに皮疹の境界は比較的不明瞭である. 
出題と解説：望月 隆（金沢医科大学 皮膚科学講座）

解答 1. Trichophyton rubrum.

2. 顔面の白癬は非定型的な臨床像を示す，衣類を十分脱がせて皮疹を診察する．内服抗真菌剤の適応を考慮する．

\section{解説}

1. Trichophyton rubrum. 体部白癬の主要原因菌は, 2006 年次皮膚真菌症疫学調査報告では T. rubrum が最多で $74.8 \%$ (235 例/314 例), 以下 T. tonsurans 10.2\%, T. mentagrophytes 4.1\%. M. canis 1.3\% と続<1). この例で は年余にわたる爪の混濁や広範囲にわたる病変から T. r u b r u m の感染を疑った. 真菌培養で頭皮の鱗屑, 背部の鱗屑, 足爪より T. rubrum が分離された.

2. 身体診察では, 頸部から背部の広範囲に鱗屑を伴った境界明瞭な紅斑を認めた（図 2). 顔面では白癬の病巣は境 界が不明瞭で中心治癒を伴わず, 鱗屑も少ないなど非定型的な臨床像を示すことが多く, 誤診例も少なくない.これを 強調するため欧米の教科書 ${ }^{2)}$ では tinea corporis とは別に tinea faciei として記載され, 本邦でも顔面白癬と記載して 注意を喚起する必要性が指摘されている3 。一方, 顔面から連続した病巣でも体幹に至ると境界が明瞭な典型的な皮疹 となり，診断も容易である．したがって主訴が顔面の皮疹であっても衣類を十分脱がせて観察することが誤診を避ける うえでも, 治療法を選択するうえでも重要なポイントである.

治療は頭部, 背部, 爪を含む広範囲の白癬であるので, 内服抗真菌剂が適応になる4)、高齢者が外用薬を背部に塗る のは困難を伴い, 顔面では外用の範囲を明確に指示することが難しく, 頭皮にも病巣があるため, 外用のみでは治療が 不十分になると予測できるかが重要なポイントである. この例では血液検査を行いつつ, テルビナフィン $125 \mathrm{mg} /$ 日を 連日内服させた. 顔面, 背部の紅斑, 頭皮の鱗屑は2力月内服した時点で消失した. 4 力内服の時点で足爪は基部か $56 \mathrm{~mm}$ 程度正常な爪甲が再生し, 治癒が期待されたが, 兴の後の受診はない.

顔面の白癬がしばしば非定型的臨床像を示すのは，ステロイド薬などの外用剂による皮疹の修飾や，多様な環境因 子 ${ }^{5)}$, たとえば外気, 日光, 洗面, 化粧, ひげ剃りなどの影響, さらに毛包や脂腺が豊富で皮脂が多く分泌され，また 角層が薄いなどの顔面の皮膚の特質など, 複数の要素が関わった結果と推察される. しかし兴の病態が十分解明された とは言いがたく, なお興味深いテーマである.

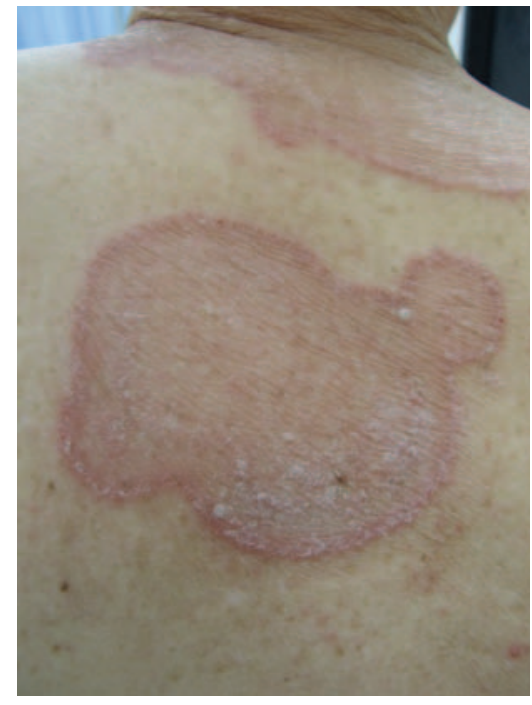

a

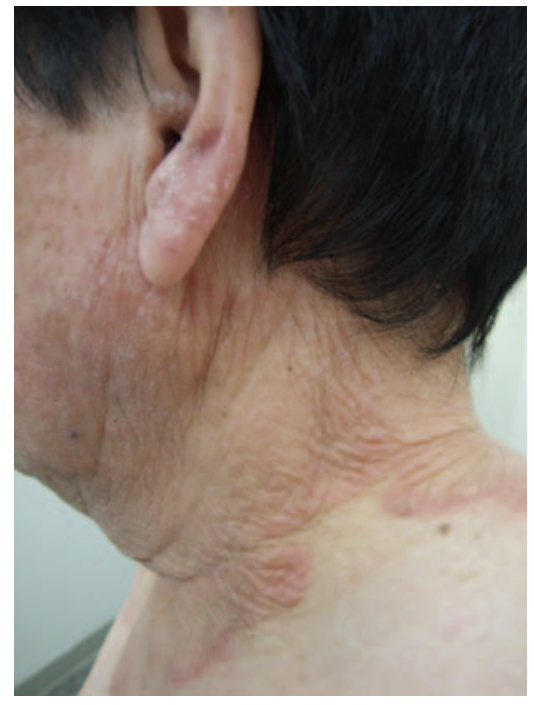

b
図 2: 初診時の皮膚所見.

a 背部では境界明瞭である。 b 顔面 から連続する病巣の体幹側で, 境界 がより明瞭である.

\section{文献}

1）清 佳浩：2006 年次皮膚真菌症疫学調査報告. Med Mycol J 53: 185-192, 2012.

2) Hay RJ, Ashbee HR: Mycology. In Rook's Textbook of Dermatology 8th ed, (Burns T, Breathnach S, Cox N, Griffiths C, ed), vol.36, pp.1-93, Wiley-Blackwell, Oxford, UK, 2010.

3）原田敬之：感染症＼cjkstart顔面白癬の多くは異型白癬になることが多いと心得るべし！ 顔面白癬. Visual Dermatol 7: 1078-1081, 2008.

4）渡辺晋一, ほか：日本皮膚科学会ガイドライン 皮膚真菌症診断治療ガイドライン. 日皮会誌 119: 851-862, 2009.

5）望月 隆, 石崎 宏: 感染症 6白癬. 皮膚科の臨床 47: 1545-1549, 2005. 